\title{
Physical and optical aerosol properties at the Dutch North Sea coast based on AERONET observations
}

\author{
J. Kusmierczyk-Michulec ${ }^{1, *}$, G. de Leeuw ${ }^{1}$, and M. M. Moerman ${ }^{1}$ \\ ${ }^{1}$ TNO-DSS, P.O. Box 96864, 2509 JG, The Hague, The Netherlands \\ * on leave from: Institute of Oceanology, Polish Academy of Sciences, Sopot, Poland
}

Received: 20 November 2006 - Published in Atmos. Chem. Phys. Discuss.: 30 January 2007

Revised: 14 May 2007 - Accepted: 18 June 2007 - Published: 2 July 2007

\begin{abstract}
Sun photometer measurements at the AERONET station at the North Sea coast in The Hague (The Netherlands) provide a climatology of optical and physical aerosol properties for the area. Results are presented from the period January 2002 to July 2003. For the analysis and interpretation these data are coupled to chemical aerosol data from a nearby station of the Dutch National Air Quality Network. This network provides $\mathrm{PM}_{10}$ and black carbon concentrations. Meteorological conditions and air mass trajectories are also used. Due to the location close to the coast, the results are strongly dependent on wind direction, i.e. air mass trajectory. In general the aerosol optical properties are governed by industrial aerosol emitted form various industrial, agricultural and urban areas surrounding the site in almost all directions over land. For maritime air masses industrial aerosols are transported from over the North Sea, whereas very clean air is transported from the NW in clean polar air masses from the North Atlantic. In the winter the effect of the production of sea salt aerosol at high wind speeds is visible in the optical and physical aerosol data. In these cases fine and coarse mode radii are similar to those reported in the literature for marine aerosol. Relations are derived between the Ångström coefficients with both the fine/coarse mode fraction and the ratio of black carbon and $\mathrm{PM}_{10}$.
\end{abstract}

\section{Introduction}

The Hague, situated in The Netherlands at the coast of the North Sea, and close to major cities, highways and industrial areas (see the map in Fig. 1), experiences a large variation in aerosol properties. Clean air is transported to The Hague in arctic air masses that travel long distances over the

Correspondence to: J. Kusmierczyk-Michulec

(jolanta.kusmierczyk@tno.nl) ocean, whereas continental air masses usually bring polluted air. The aerosol load is augmented by local sources.

TNO $\left(52^{\circ} 06^{\prime} 35^{\prime \prime} \mathrm{N} ; 04^{\circ} 19^{\prime} 36^{\prime \prime}\right)$ is situated at the outskirts of The Hague at $2.5 \mathrm{~km}$ from the North Sea, separated by an uninhabited dune area. Hence, in northwesterly winds the air masses reaching the site are only influenced by natural local sources such as sea spray produced in the surf zone (De Leeuw et al., 2000) and emissions from the vegetated sand dunes. In westerly and southwesterly winds the air masses are influenced by emissions over the UK. In contrast, to the south and southwest there are major industrial sources such as the Rotterdam harbour area Europoort with petrochemical industries and the urban agglomeration of The Hague which extends to the southeast and east. To the northeast are a large airport (Schiphol) and urban agglomerations such as Amsterdam and Utrecht. Major highways are all around from the south to the north east. Obviously the various environments influence the aerosol optical properties observed at The Hague where good visibility is associated with north westerly winds and low visibility occurs when the wind is from the east to south sector (Lamberts and de Leeuw, 1986).

In this paper we present results from a study on the optical aerosol properties at the North Sea coast, based on sun photometer measurements made in The Hague, on the premises of the TNO, between January 2002 and July 2003. The station is part of the AERONET network (http://aeronet. gsfc.nasa.gov) (Holben et al., 2001). The results available from AERONET are coupled to chemical aerosol information from a nearby station that is part of the Dutch National Air Quality Network (LML) operated by RIVM (http: //www.rivm.nl/milieukwaliteit/lucht/). This station provides $\mathrm{PM}_{10}$ and $\mathrm{BC}$, which are used in the interpretation of the spectral aerosol optical depth and derived aerosol properties that are routinely available from AERONET. Local meteorological conditions and backward air mass trajectories are also used. Seasonal differences are discussed. The empirical orthogonal function (EOF) method (e.g. Lorenz, 1956;

Published by Copernicus Publications on behalf of the European Geosciences Union. 


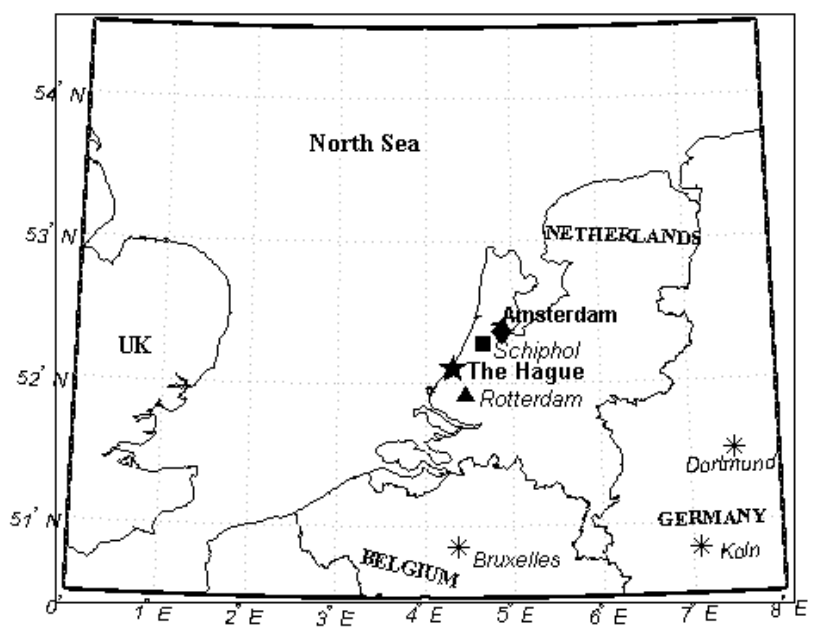

Fig. 1. Map of the Netherlands showing the location of The Hague and other large cities in the vicinity.

Preisendorfer, 1988) is applied to extract the main spectral features corresponding to the main aerosol types and to analyze their variability.

\section{Experimental}

The data presented in this paper were derived from measurements with a CIMEL sun photometer. The technical details of the instrument are described in the Cimel Sun Photometer Manual (http://aeronet.gsfc.nasa.gov). The instrument measures the aerosol optical depth at four wavelengths $(440 \mathrm{~nm}, 670 \mathrm{~nm}, 870 \mathrm{~nm}$ and $1020 \mathrm{~nm})$, and the sky radiance in aerosol channels in the azimuth plane (the almucantar technique) and in the principal plane. These data are used in the AERONET standard procedures to retrieve information on columnar aerosol characteristics such as the aerosol optical depth, Ångström coefficient and size information. Data processing, cloud-screening algorithm, and inversion techniques are described by Holben et al. (1998, 2001), Eck et al. (1999), Smirnov et al. (2000), Dubovik and King (2000), and Dubovik et al. (2000).

Information on the aerosol chemical composition is available from LML. The station that is most representative of the AERONET site in The Hague is rural station 444 in De Zilk. The distance between both locations is approximately $35 \mathrm{~km}$. De Zilk is situated in the NE direction from The Hague. Both stations are situated just east of the dunes, i.e. about $2.5 \mathrm{~km}$ from the coastline. Relevant aerosol data available from this station are $\mathrm{PM}_{10}$ (particulate matter with an aerodynamic diameter of less than $10 \mu \mathrm{m}$ ) and black carbon concentrations. Black carbon (particles mostly smaller than $2.5 \mu \mathrm{m}$ ) is available as daily values and $\mathrm{PM}_{10}$ is available on an hourly basis.

RIVM's National Air Quality Monitoring Network in the Netherlands performs continuous PM measurements i.e.
$\mathrm{PM}_{10}$ and $\mathrm{PM}_{2.5}$, using an FAG-type $\beta$-dust monitor (Van Elzakker, 2000). The sampling air is heated (to $50^{\circ} \mathrm{C}$ ) in order to remove water from aerosol particles (Buringh and Opperhuizen, 2002). The drawback of the heating is a removal of semi-volatile compounds e.g. ammonium nitrate which leads to the losses in PM measurements. The correction methods for a systematic underestimation by the sampling equipment are described by Hammingh (2001) and discussed in detail by Buringh and Opperhuizen (2002). The amount of black carbon is estimated based on the PM measurements using the so-called light-reflectance method (Buringh and Opperhuizen, 2002).

\section{Methodology}

\subsection{The analysis methods for the AERONET data}

The analysis presented is in this paper focuses on data collected from January 2002 to July 2003. Only Level 2.0 data, i.e., quality assured and cloud free, are used (cf. http: //aeronet.gsfc.nasa.gov). The hourly mean values of the aerosol optical depth at four wavelengths $\lambda$ were calculated. The Ångström coefficient $\alpha$ (also known as Ångström exponent or Ångström parameter) was obtained from fitting the spectral aerosol optical depth spectrum $\tau_{A}(\lambda)$ to a power law function (Ångström, 1929):

$\tau_{A}(\lambda)=\gamma \lambda^{-\alpha}$,

following the AERONET procedure, in the spectral range from $440 \mathrm{~nm}$ to $870 \mathrm{~nm}$.

Aerosol volume size distributions in the radius range 0.05 $15 \mu \mathrm{m}$ at the AERONET site have been calculated with the retrieval algorithm described by Dubovik and King (2000) and Dubovik et al. (2000, 2002). The algorithm allows for the simultaneous retrieval of aerosol particle size distribution and complex refractive index from spectral optical depth measurements combined with the angular distribution of sky radiance measured at different wavelengths. The algorithm assumes that the atmosphere is vertically homogeneous and that the aerosol particles are spherical.

The aerosol volume distributions are modelled as a bimodal lognormal function (e.g., Shettle and Fenn, 1979; Remer and Kaufman, 1998; Hess et al., 1998):

$\frac{d V(r)}{d \ln r}=\sum_{i=1}^{2} \frac{C_{v, i}}{\sigma_{i} \sqrt{2 \pi}} \exp \left\{-\frac{\left(\ln r-\ln r_{v, i}\right)^{2}}{2 \sigma_{i}^{2}}\right\}$

where $C_{v}$ is the particle volume concentration, $r_{v}$ - the median radius and $\sigma-$ the standard deviation. The first mode indicated by $i=1$ refers to a "fine mode" and the second one, $i=2$, corresponds to a "coarse mode". The fine and coarse modes are divided by a radius $r=0.6 \mu \mathrm{m}$ (Dubovik et al., 2002).

The interpretation of the results derived from the sun photometer measurements is supported by the air mass backward 
trajectories available from AERONET. The trajectories are based on the National Aeronautics and Space Administration (NASA) Goddard kinematic trajectory model (Schoeberl and Newman, 1995; Pickering et al., 2001). The computed air parcels movements are driven by assimilated meteorological data products obtained from the NASA Goddard Global Modeling and Assimilation Office which supplies the meteorological information in a 1.25 degree longitudinal and 1 degree latitudinal spatial resolution on 55 hybrid sigmapressure vertical levels ( $\mathrm{T}$. Kucsera, personal communication). The trajectory analyses start at four pressure levels i.e. at $950,850,700$, and $500 \mathrm{hPa}$, which roughly correspond to altitudes of $0.5,1.5,3$ and $5 \mathrm{~km}$.

\subsection{The Empirical Orthogonal Function (EOF) method}

Let $\tau_{A i}\left(\lambda_{j}\right)$ be an aerosol optical depth spectrum, where the subscript $i$ symbolizes each successive measurement, $i=1, \ldots, N$, and the subscript $j$ corresponds to the number of spectral channels, $j=1, \ldots, M$, and $M=4$. The mean aerosol optical depth for each wavelength is given by:

$$
<\tau_{A}\left(\lambda_{j}\right)>=\frac{1}{N} \sum_{i=1}^{N} \tau_{A i}\left(\lambda_{j}\right) \quad j=1, \ldots, M
$$

and the fluctuations from the mean $* \tau_{A i}\left(\lambda_{j}\right)$ are:

$$
\begin{aligned}
* \tau_{A i}\left(\lambda_{j}\right) & =\tau_{A i}\left(\lambda_{j}\right)-<\tau_{A}\left(\lambda_{j}\right)> \\
i & =1, \ldots, N ; j=1, \ldots, M
\end{aligned}
$$

The fluctuation spectra are approximated by expanding them into a series of orthogonal functions $h_{k}\left(\lambda_{j}\right)$ :

$$
* \tau_{A i}\left(\lambda_{j}\right)=\sum_{k=1}^{M} h_{k}\left(\lambda_{j}\right) \beta_{i k} \quad i=1, \ldots, N ; j=1, \ldots, M
$$

where the functions $h_{k}\left(\lambda_{j}\right)$ should fulfill the conditions of orthogonality and be normalized.

$\sum_{j=1}^{M} h_{i}\left(\lambda_{j}\right) h_{k}\left(\lambda_{j}\right)=M \delta_{i k}$,

where $\delta_{i k}=0$ for $i \neq k, 1$ for $i=k$

The functions $h_{k}\left(\lambda_{j}\right)$ are called modes or main components, coefficients $\beta_{i k}$ are called amplitude functions or simply amplitudes (e.g., Lorenz, 1956; Preisendorfer, 1988). In the EOF method, functions $h_{k}$ are chosen as eigenfunctions (eigenvectors) of the covariance matrix $\mathfrak{s}\left(\lambda_{i}, \lambda_{j}\right)$,

$\Im\left(\lambda_{i}, \lambda_{j}\right)=\frac{1}{N} \sum_{k=1}^{N} * \tau_{A k}\left(\lambda_{i}\right) * \tau_{A k}\left(\lambda_{j}\right), i, j=1, \ldots, M$

which, at the same time, are solutions of

$$
\sum_{i=1}^{M} \mathfrak{s}\left(\lambda_{i}, \lambda_{j}\right) h_{k}\left(\lambda_{i}\right)=\wp_{k} h_{k}\left(\lambda_{j}\right) \quad j, k=1, \ldots, M
$$

\begin{tabular}{|c|c|c|c|c|}
\hline Month & $\mathrm{N}_{\text {meas }}$ & $\mathrm{N}_{\text {days }}$ & $\tau_{A}(555)$ & $\alpha$ \\
\hline \multicolumn{5}{|c|}{ Year 2002} \\
\hline I & 33 & 10 & $0.10-0.15$ & $0-0.2$ \\
\hline II & 43 & 9 & $0-0.05$ & $1.4-1.6$ \\
\hline III & 48 & 7 & $0.15-0.25$ & $1.6-1.8$ \\
\hline IV & 124 & 20 & $0.10-0.15$ & $1.4-1.6$ \\
\hline V & 69 & 15 & $0.10-0.15$ & $1.0-1.2$ \\
\hline VI & 101 & 16 & $0.05-0.10$ & $1.4-1.6$ \\
\hline VII & 98 & 14 & $0.25-0.30$ & $1.6-1.8$ \\
\hline VIII & 87 & 16 & $0.05-0.10$ & $1.6-1.8$ \\
\hline IX & 96 & 12 & $0.05-0.10$ & $1.8-2.0$ \\
\hline$X$ & 49 & 9 & $0.10-0.15$ & $1.4-1.6$ \\
\hline XI & 21 & 6 & $0.10-0.15$ & $0.6-0.8$ \\
\hline XII & 3 & 1 & $0.10-0.15$ & $1.4-1.6$ \\
\hline \multicolumn{5}{|c|}{ Year 2003} \\
\hline I & 29 & 7 & $0.10-0.15$ & $1.4-1.6$ \\
\hline II & 108 & 17 & $0.15-0.20$ & $1.2-1.4$ \\
\hline III & 119 & 17 & $0.15-0.20$ & $1.0-1.2$ \\
\hline IV & 124 & 16 & $0.20-0.25$ & $1.4-1.6$ \\
\hline V & 58 & 6 & $0.30-0.35$ & $1.6-1.8$ \\
\hline VI & 156 & 24 & $0.10-0.15$ & $1.4-1.6$ \\
\hline
\end{tabular}

Table 1. The most probable values of the aerosol optical depth and Ångström coefficient $\alpha$.

where $\wp_{k}$ are eigenvalues of the covariance matrix. Eigenvalues $\wp_{k}$ and eigenvectors $h_{k}$ are calculated by Jacobi's method (Ralston, 1975).

Using Eqs. (4) and (5), the values of aerosol optical depth can be derived from:

$\tau_{A i}\left(\lambda_{j}\right)=\sum_{k=1}^{L} h_{k}\left(\lambda_{j}\right) \beta_{i k}+<\tau_{A}\left(\lambda_{j}\right)>\quad i=1, \ldots, N$

where $L$ is the number of modes chosen in accordance with the criterion $\Re(L)$, defining the contribution of the eigenvalues to the total variance,

$\Re(L)=\sum_{i=1}^{L} \wp_{i} / \sum_{i=1}^{M} \wp_{i}$

Values of $\Re(L)$ are assumed to be of the order of $0.90-0.95$ (e.g., Nielsen, 1979; Jankowski, 1994). Mode $h_{1}$ contains the maximum energy of the entire data set, mode $h_{2}$ contains the maximum energy of what is left after the first mode has been subtracted, etc.

\section{Results}

\subsection{Aerosol optical depth}

An overview of the sun photometer data is presented in Fig. 2, which shows the time series of the aerosol optical depth at $440 \mathrm{~nm}$ (Fig. 2a), and the Ångström coefficients 


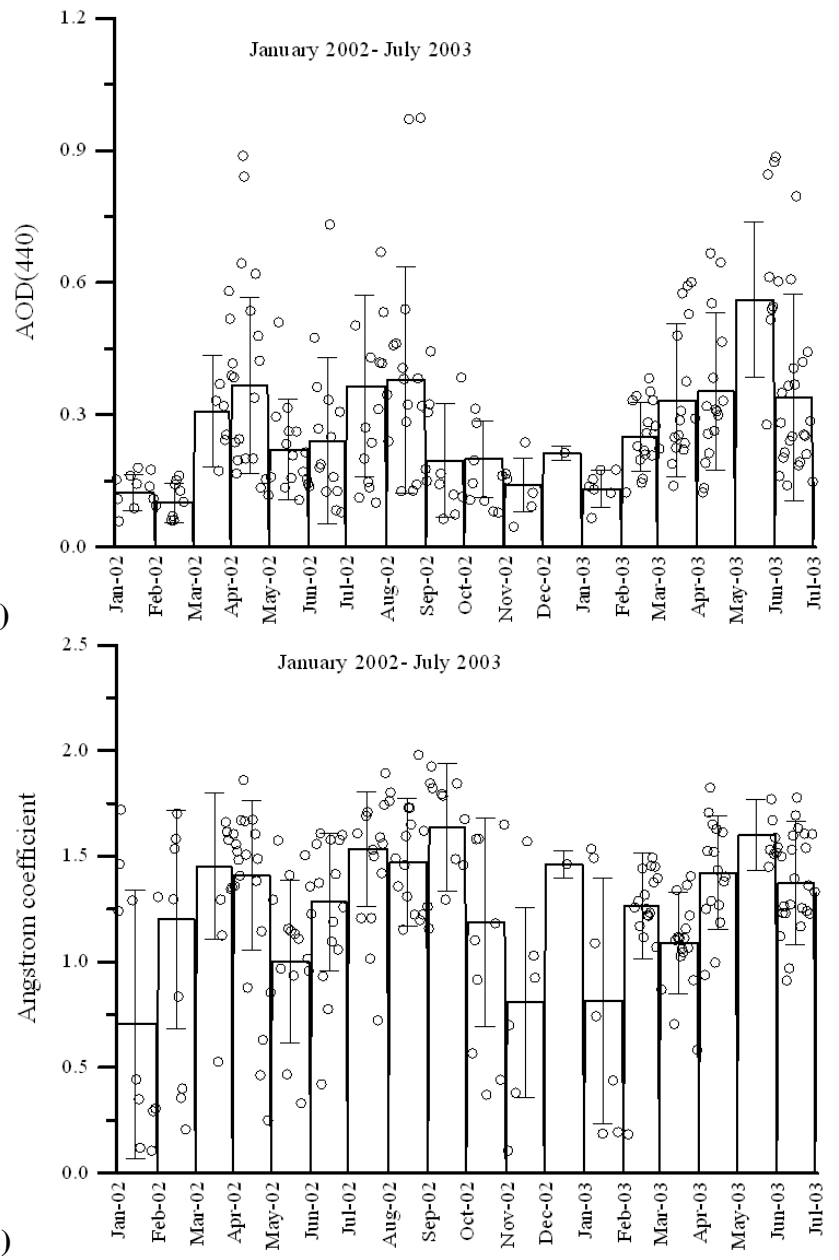

Fig. 2. Overview of the aerosol optical depth at $440 \mathrm{~nm}$ (panel a), and the Ångström coefficients (panel b) measured in The Hague from January 2002 to July 2003. The daily mean values are indicated by open circles. The monthly mean values are presented as columns with standard deviation as error bars.

(Fig. 2b). The aerosol optical depth varies from lower than 0.05 to 1.4. Gaps between data occur when there were no measurements due to the presence of clouds. Cloud occurrence at the coast of the Netherlands is associated with certain weather patterns. Westerly winds transport air masses over the North Sea where they pick up moisture which often results in the formation of clouds. In contrast, when the wind is from the east, i.e., from over land, the air is often dry and the sky is clear. Hence, although the governing wind direction in The Netherlands is SW, clear sky is often associated with easterly winds. Therefore, also the aerosol optical depth observations are predominantly made in easterly wind directions (Fig. 3). Because in The Hague easterly winds are usually associated with air masses that passed over major emission regions also the distribution of optical properties derived from sun photometer measurements is expected to be somewhat biased to high values.
January 2002 - July 2003

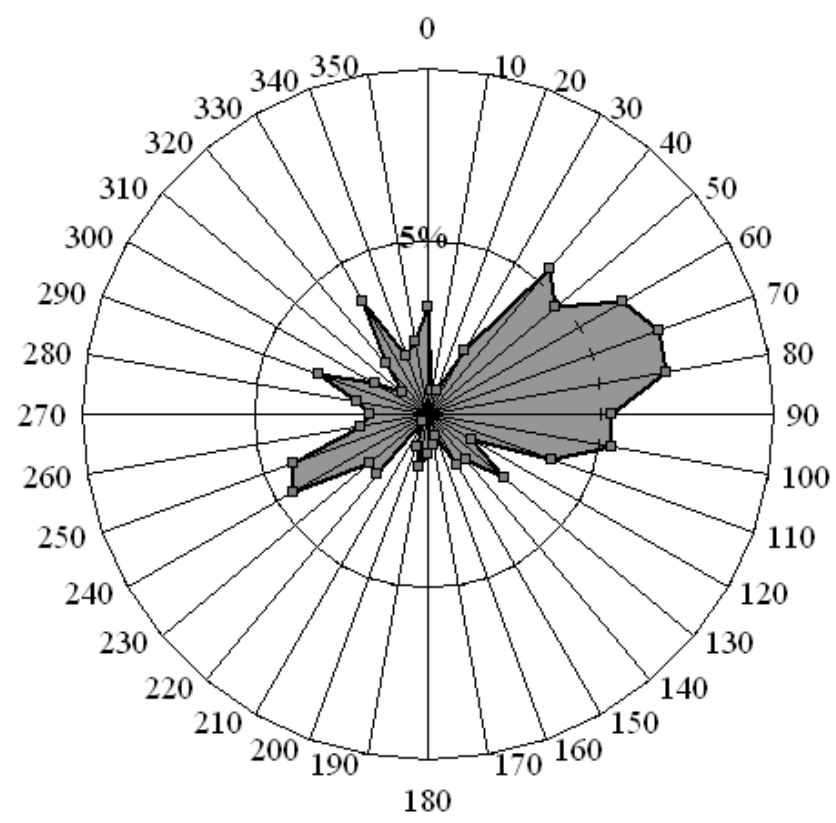

Fig. 3. Frequency of occurrence of wind directions during the aerosol optical depth observations. The circles indicate the $5 \%$ and $10 \%$ probabilities of occurrence.

Based on the frequency histograms of $\tau_{A}(555)$, the most probable values i.e. the values at which the probability distribution of $\tau_{A}(555)$ has its maximum, can be determined. These values, for each month, are reported in Table 1. The wavelength $555 \mathrm{~nm}$ was selected because it is representative for the visual range which is often used as a reference. The values were obtained by interpolation between $440 \mathrm{~nm}$ and $670 \mathrm{~nm}$, using the Ångström coefficients. The most probable values of the aerosol optical depth at $555 \mathrm{~nm}$ are between 0.1 and 0.2 , although excursions to both lower and higher values are frequently observed.

Figure $2 b$ shows the Ångström coefficients during the study period. The values vary from close to 0 to about 2 , indicating large variability of the shape of the aerosol particle size distributions. Based on the frequency histograms of $\alpha$, the most probable values i.e. the values at which the probability distribution of $\alpha$ has its maximum, were determined for each month. The results are presented in Table 1. Often the most probable values are above 1.4. During two months, January and November, the most probable values are much smaller. There is no clear trend in the variation of the Ångström coefficients.

\section{2 Ångström coefficient versus $\mathrm{PM}_{10}, \mathrm{BC}$ and wind direc- tion sector}

When the particle size distribution is dominated by small particles, usually associated with pollution, the Ångström 
Table 2. Ratio of $\mathrm{BC}$ to $\mathrm{PM}_{10}$ (median, mean values and the standard deviation) obtained for different ranges of the Angstrom coefficient $\alpha$. For each group the median values of wind direction WD and wind speed $u$ are also presented.

\begin{tabular}{|c|c|c|c|c|c|c|c|}
\hline range of $\alpha$ & $\alpha$ & median & 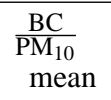 & std & $u[\mathrm{~m} / \mathrm{s}]$ & WD [deg] & $\mathrm{N}$ \\
\hline \multicolumn{8}{|c|}{$\mathrm{PM}_{10}<50$} \\
\hline $0.0-0.2$ & 0.12 & 0.022 & 0.022 & 0.02 & 9.0 & 240 & 9 \\
\hline $0.2-0.4$ & 0.32 & 0.011 & 0.049 & 0.04 & 7.0 & 275 & 20 \\
\hline $0.4-0.6$ & 0.49 & 0.042 & 0.083 & 0.05 & 6.0 & 244 & 30 \\
\hline $0.6-0.8$ & 0.73 & 0.060 & 0.109 & 0.06 & 5.0 & 242 & 32 \\
\hline $0.8-1.0$ & 0.92 & 0.111 & 0.146 & 0.05 & 5.5 & 180 & 57 \\
\hline $1.0-1.2$ & 1.10 & 0.071 & 0.110 & 0.06 & 5.0 & 244 & 117 \\
\hline $1.2-1.4$ & 1.31 & 0.091 & 0.135 & 0.06 & 5.0 & 200 & 137 \\
\hline $1.4-1.6$ & 1.52 & 0.139 & 0.169 & 0.05 & 4.0 & 120 & 221 \\
\hline $1.6-1.8$ & 1.69 & 0.185 & 0.212 & 0.05 & 4.0 & 89 & 174 \\
\hline $1.8-2.0$ & 1.88 & 0.182 & 0.224 & 0.05 & 4.0 & 70 & 53 \\
\hline \multicolumn{8}{|c|}{$50 \leq \mathrm{PM}_{10}<200$} \\
\hline $0.0-0.2$ & 0.14 & 0.036 & 0.027 & 0.02 & 11 & 243 & 12 \\
\hline $0.2-0.4$ & 0.31 & 0.018 & 0.030 & 0.02 & 10 & 240 & 18 \\
\hline $0.4-0.6$ & 0.48 & 0.015 & 0.034 & 0.03 & 9.0 & 240 & 18 \\
\hline $0.6-0.8$ & 0.77 & 0.065 & 0.069 & 0.05 & 7.0 & 163 & 8 \\
\hline $0.8-1.0$ & 0.92 & 0.152 & 0.142 & 0.05 & 4.0 & 108 & 31 \\
\hline $1.0-1.2$ & 1.10 & 0.127 & 0.138 & 0.05 & 4.0 & 108 & 73 \\
\hline $1.2-1.4$ & 1.29 & 0.153 & 0.167 & 0.05 & 4.0 & 93 & 98 \\
\hline $1.4-1.6$ & 1.51 & 0.150 & 0.161 & 0.05 & 4.0 & 110 & 137 \\
\hline $1.6-1.8$ & 1.65 & 0.122 & 0.130 & 0.05 & 4.0 & 90 & 94 \\
\hline $1.8-2.0$ & 1.88 & 0.133 & 0.122 & 0.04 & 3.0 & 130 & 24 \\
\hline
\end{tabular}

coefficients are high; in clear conditions they are usually low. Therefore a correlation is expected between the Ångström coefficients and chemical composition. The different data were time synchronized and all data were divided into 10 subgroups, corresponding to Ångström coefficient values ranging from 0 to 2 , with a step of 0.2 (see Table 2). The data were further divided into subgroups with $\mathrm{PM}_{10}<50 \mu \mathrm{g} / \mathrm{m}^{3}$ (clean air according to the EU air quality norm) and with $50 \mu \mathrm{g} / \mathrm{m}^{3} \leq \mathrm{PM}_{10}<200 \mu \mathrm{g} / \mathrm{m}^{3}$ (moderate smog).

Table 2 and Fig. 4 show that in both cases the Ångström coefficient increases with the percentage contribution of BC to $\mathrm{PM}_{10}$. The solid curves in Fig. 4 are 3rd degree polynomials fitted to the data.

On clean days $\mathrm{BC} / \mathrm{PM}_{10}$ increases monotonously with the Ångström coefficient whereas on days with moderate smog a maximum is observed for $\alpha$ between 1.2 and 1.6. This maximum suggests that the further increase of $\mathrm{PM}_{10}$ is not caused by increase of BC, but by other species. However, because no other measurements are available this cannot be further interpreted. The relation obtained for the clean days is similar to that derived from observations over the Baltic Sea (Kusmierczyk-Michulec et al., 2002), with coefficients that are within the experimental error.

Table 2 also shows the wind speed and wind direction. Wind speed is a factor which influences both the generation and the removal of aerosol particles, i.e. both production and removal increase with increasing wind speed. In particular, over sea the amount of sea spray aerosol increases with $u^{3}$ when the wind speed is larger than $3-4 \mathrm{~m} / \mathrm{s}$ causing wave breaking and the generation of sea spray particles. Table 2 shows that the lowest Ångström coefficient values were observed at relatively high wind speed, $6-11 \mathrm{~ms}$, during wind from sea $\left(201^{\circ}-39^{\circ}\right)$. Likely production of sea spray and the enhanced deposition of fine particles worked together to change the ratio between fine and coarse particles.

Table 2 shows that both the lower values of the Ångström coefficients and the changes in the contribution of $\mathrm{BC}$ are usually associated with wind from sea $\left(201^{\circ}\right.$ to $\left.39^{\circ}\right)$ whereas the higher Ångström coefficients are associated with wind from land $\left(40^{\circ}\right.$ to $\left.200^{\circ}\right)$. This is illustrated by the polar diagram of the Ångström coefficients vs. wind direction in Fig. 5. The industrial aerosol type characterized by $\alpha \geq 1.5$ may be observed from all wind directions. Small Ångström coefficients between 0.6 and 0.97 are observed in the N-NNE $\left(0^{\circ}-20^{\circ}\right)$, NE-ESE $\left(50^{\circ}-110^{\circ}\right)$ and SE-S $\left(140^{\circ}-180^{\circ}\right)$ wind sectors and Ångström coefficients between $0.49-0.6$ are observed in NNE-NE $\left(20^{\circ}-50^{\circ}\right)$ and $\operatorname{ESE}\left(110^{\circ}-120^{\circ}\right)$ wind sectors. Maritime dominated aerosol with Ångström coefficients between 0.025 and 0.48 are observed in the SW-WNW $\left(220^{\circ}-300^{\circ}\right)$ and NW-N $\left(320^{\circ}-350^{\circ}\right)$ wind sectors.

Overlaying Fig. 5 with the map presented in Fig. 1 shows that the highest Ångström coefficients are associated with 


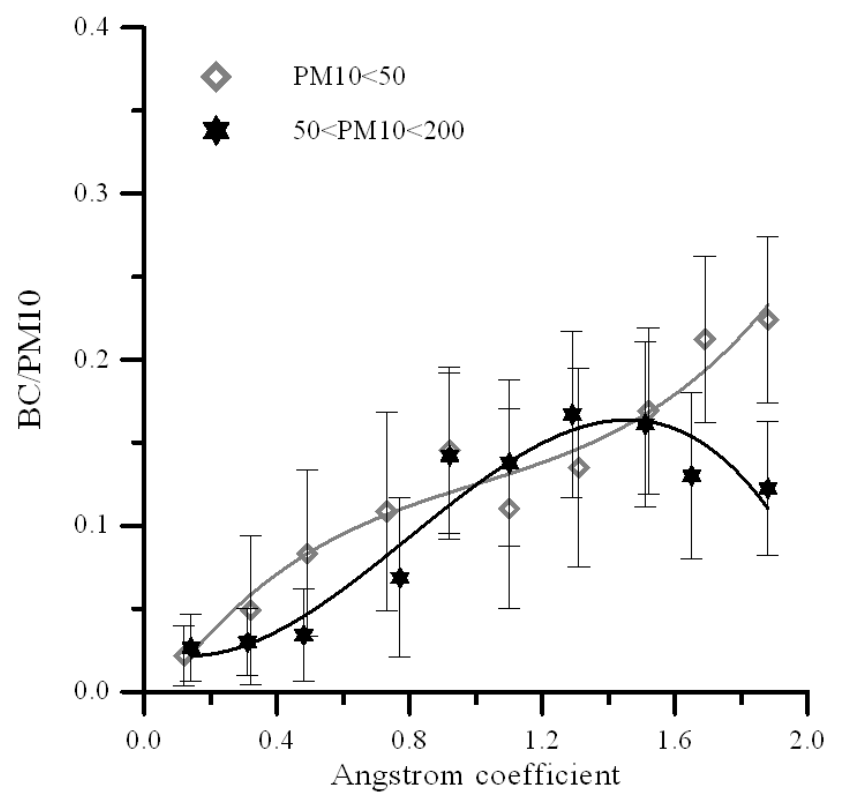

Fig. 4. The mean values of $B C / \mathrm{PM}_{10}$ with the standard deviation indicated as error bars versus Ångström coefficient. Data points are listed in Table 2.

large cities and industrial regions to the NE, SE and S. The industrial influences observed in wind directions from land (NE-SW) can be ascribed to the presence of local sources (see Fig. 1), whereas in wind from sea (SW-NE) the observed presence of fine particles is mainly due to transport of aerosol produced further away.

To further investigate the various influences on the observed aerosol optical depth values, the Empirical Orthogonal Function (EOF) method (Preisendorfer, 1988) was applied to the aerosol optical depth spectra.

4.3 Application of the EOF method to the aerosol optical depth measurements in The Hague

The EOF method has been used to analyze, e.g., large meteorological datasets (e.g., Lorenz, 1956) or the variability of water temperature, salinity, density (e.g., Jankowski, 1994) and sea level (e.g., Nielsen, 1979). KusmierczykMichulec and Darecki (1996) and Kusmierczyk-Michulec et al. (1999) applied the EOF method to the aerosol optical depth over the Baltic Sea to understand the temporal and spatial variability. Three different air mass types could be distinguished, each with their own characteristic aerosol properties corresponding to different residence times over sea. Effects of thermal stratification on the aerosol optical depth were identified. The EOF method was also successfully applied to data collected at the Polish coast (Sopot, Hel) in the period from July 1997 to May 1999 to distinguish between different aerosol types as function of the wind direction (Kusmierczyk-Michulec and Marks, 2000).

\section{Angstrom coefficient, year 2002/2003}

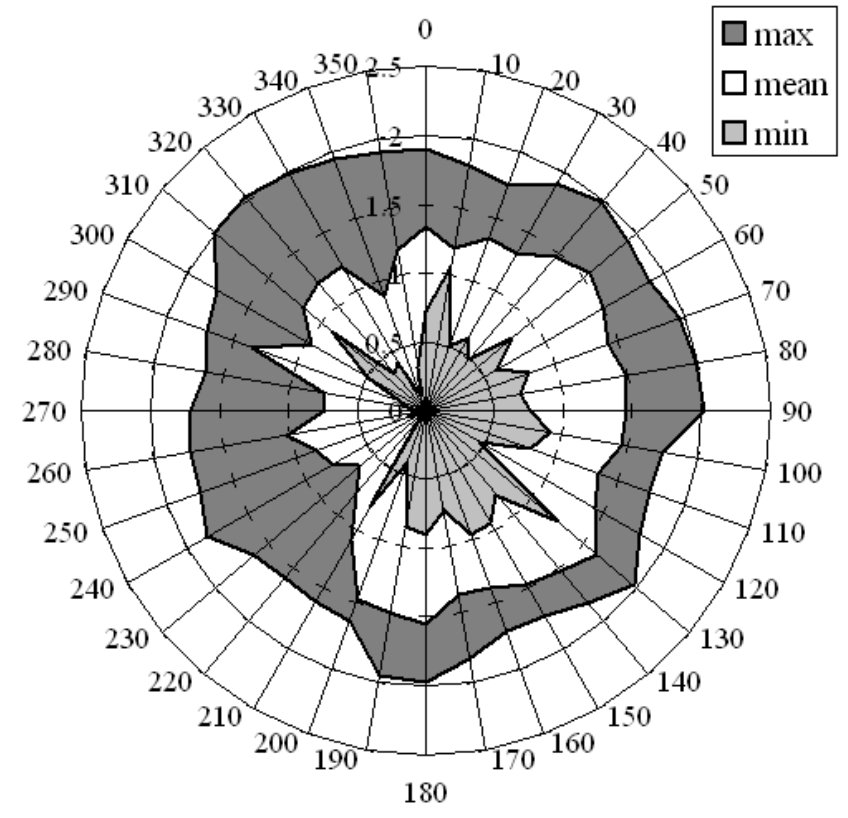

Fig. 5. Polar diagram showing of the minimum, mean and maximum values of the Ångström coefficients as a function of wind direction.

In this paper the EOF method was used to analyze the aerosol optical depth data collected in The Hague. Data were separated into subsets corresponding to four seasons, for either onshore or offshore wind. Seasons were defined as: winter (January, February, November and December), spring (March, April), summer (May, June, July and August) and autumn (September and October). The wind blowing from the land was attributed to the wind direction sector NE-SSE $\left(40^{\circ}\right.$ to $\left.200^{\circ}\right)$, and the wind from the sea was indicated by the wind direction sector SSE-NE $\left(201^{\circ}\right.$ to $\left.39^{\circ}\right)$.

Table 3 presents the EOF results, including the values of the coefficients $\alpha$ and $\gamma$ (see Eq. 1) for both $\left\langle\tau_{A}(\lambda)>\right.$ and $h_{1}(\lambda)$; the mean values of the aerosol optical depth $<\tau_{A}(555)>$ and its standard deviation $\sigma_{\tau}$, as well as the maximum and minimum amplitude for each data subset. In all situations, the contribution of the eigenvalues to the total variance $\Re$ was higher than $92 \%$. This implies that only the first eigenvector is significant and higher modes can be neglected. Therefore in all cases Eq. (9) can be written as:

$\tau_{A i}\left(\lambda_{j}\right)=h_{1}\left(\lambda_{j}\right) \beta_{i 1}+<\tau_{A}\left(\lambda_{j}\right)>\quad i=1, \ldots, N$

The deviation from the mean value (mean spectrum) $<\tau_{A}\left(\lambda_{j}\right)>$ is expressed by the product of the amplitude function $\beta_{i 1}$ and the first mode $h_{1}$.

The added value of Eq. (11) is that instead of analyzing the differences between the aerosol optical depth values at a single wavelength we can analyze the differences between the vectors describing the aerosol optical depth over the whole range of discrete wavelengths. 
Table 3. The seasonal optical characteristics of aerosols over The Hague.

\begin{tabular}{|c|c|c|c|c|c|c|c|c|c|}
\hline \multirow{2}{*}{$\begin{array}{l}\text { Season } \\
\text { wind } \\
\text { sector }\end{array}$} & \multirow[t]{2}{*}{$\left\langle\tau_{A}(555)\right\rangle$} & \multirow[t]{2}{*}{$\sigma_{\tau}$} & \multicolumn{2}{|c|}{$\left\langle\tau_{A}(\lambda)\right\rangle$} & \multicolumn{2}{|c|}{$\mathrm{h}_{1}(\lambda)$} & \multirow[t]{2}{*}{$\beta_{\min }$} & \multirow[t]{2}{*}{$\beta_{\max }$} & \multirow[t]{2}{*}{$\mathrm{N}$} \\
\hline & & & $\alpha$ & $\gamma$ & $\alpha$ & $\gamma$ & & & \\
\hline \multicolumn{10}{|c|}{ spring 2002/2003 } \\
\hline $40^{\circ}-200^{\circ}$ & 0.257 & 0.13 & 1.411 & 0.111 & 1.428 & 0.252 & -0.323 & 0.731 & 285 \\
\hline $201^{\circ}-39^{\circ}$ & 0.246 & 0.13 & 1.120 & 0.127 & 1.222 & 0.286 & -0.307 & 0.905 & 129 \\
\hline \multicolumn{10}{|c|}{ summer $2002 / 2003$} \\
\hline $40^{\circ}-200^{\circ}$ & 0.303 & 0.16 & 1.496 & 0.126 & 1.409 & 0.254 & -0.398 & 1.125 & 199 \\
\hline $201^{\circ}-39^{\circ}$ & 0.212 & 0.15 & 1.341 & 0.096 & 1.435 & 0.250 & -0.289 & 1.109 & 373 \\
\hline \multicolumn{10}{|c|}{ autumn 2002} \\
\hline $40^{\circ}-200^{\circ}$ & 0.139 & 0.07 & 1.473 & 0.058 & 1.406 & 0.253 & -0.188 & 0.485 & 110 \\
\hline $201^{\circ}-39^{\circ}$ & 0.143 & 0.07 & 1.493 & 0.059 & 2.621 & 0.111 & -0.168 & 0.319 & 36 \\
\hline \multicolumn{10}{|c|}{ winter $2002 / 2003$} \\
\hline $40^{\circ}-200^{\circ}$ & 0.146 & 0.07 & 1.309 & 0.067 & 1.299 & 0.272 & -0.190 & 0.264 & 168 \\
\hline $201^{\circ}-39^{\circ}$ & 0.125 & 0.04 & 0.385 & 0.098 & -0.246 & 0.515 & -0.168 & 0.150 & 69 \\
\hline
\end{tabular}

As an example, the amplitudes for the winter data set for the SSW-NE sector are presented in Fig. 6. From this graph we can identify days when the amplitude was close to $\beta_{\min }$, $\beta_{\max }$ or $\beta \rightarrow 0$. For instance, data from 24 January 2003 were chosen as representative for the mean spectrum of the aerosol optical depth, defined by $\beta \rightarrow 0$. These days can be matched with the chemical data and the retrieved aerosol size distributions for the interpretation of the differences between the extreme cases in terms of the differences in the associated size distributions and aerosol types.

\section{Interpretation of the EOF results}

\subsection{The amplitude function}

For each season and wind direction sector the optical data $\tau_{A}(555)$ and $\alpha$ were grouped together with the corresponding chemical data $\mathrm{PM}_{10}$ and the amplitude values. The chemical and optical data in Table 4 represent the median values and are given for 5 ranges of the amplitude values: $\beta_{\max }$, $1 / 2 \times \beta_{\max }, \beta \rightarrow 0,1 / 2 \times \beta_{\min }$ and $\beta_{\min }$.

Figure 7 shows the spectral distribution of the aerosol optical depth with their extremes. The exact values of the aerosol optical depth for other wavelengths may be reconstructed using Eq. (11) and proper parameters from Table 3. The highest values of the amplitude function correspond to the highest values of the $\mathrm{PM}_{10}$ concentration and $\tau_{A}(555)$. There are small variations between seasons. The values of $\tau_{A}(555)$ in spring and summer were much higher than in autumn and winter. However, there is no significant direct correlation between $\tau_{A}(555)$ and $\mathrm{PM}_{10}$ in any season or wind sector, except in the winter with wind from land (Correlation Coefficient=0.60, see Fig. 8). Such correlations have been observed in parts of the USA (Wang and Christopher, 2003; Hutchison,

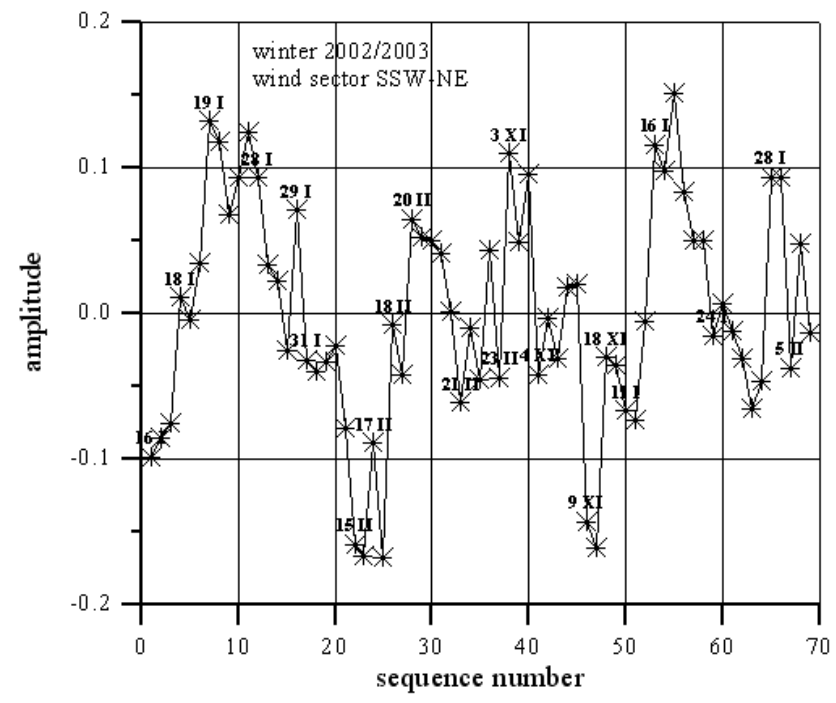

Fig. 6. Amplitudes for the winter data set. Annotations correspond to the observation date, i.e. 6 I indicates 6 January.

2003) and for Ispra (Chu et al., 2003), whereas at other sites there was no correlation (e.g., Engel-Cox et al., 2004).

It should be emphasized that the aerosol optical depth values represent vertical column-integrated properties whereas the $\mathrm{PM}_{10}$ data are the "surface" data. This kind of comparison is justified in the well-mixed boundary layer. The mixing layer height (MLH) can be determined e.g. from ceilometer backscatter profiles. Such measurements were done in The Netherlands in the experimental site in Cabauw, situated about $64 \mathrm{~km}$ from The Hague. Unfortunately, these measurements are not yet publicly available. A statistical analysis of the MLH data collected between 2000 and 2006 is presented by De Haij et al. (2006). The results show the diurnal and seasonal cycle. During the winter and autumn the 

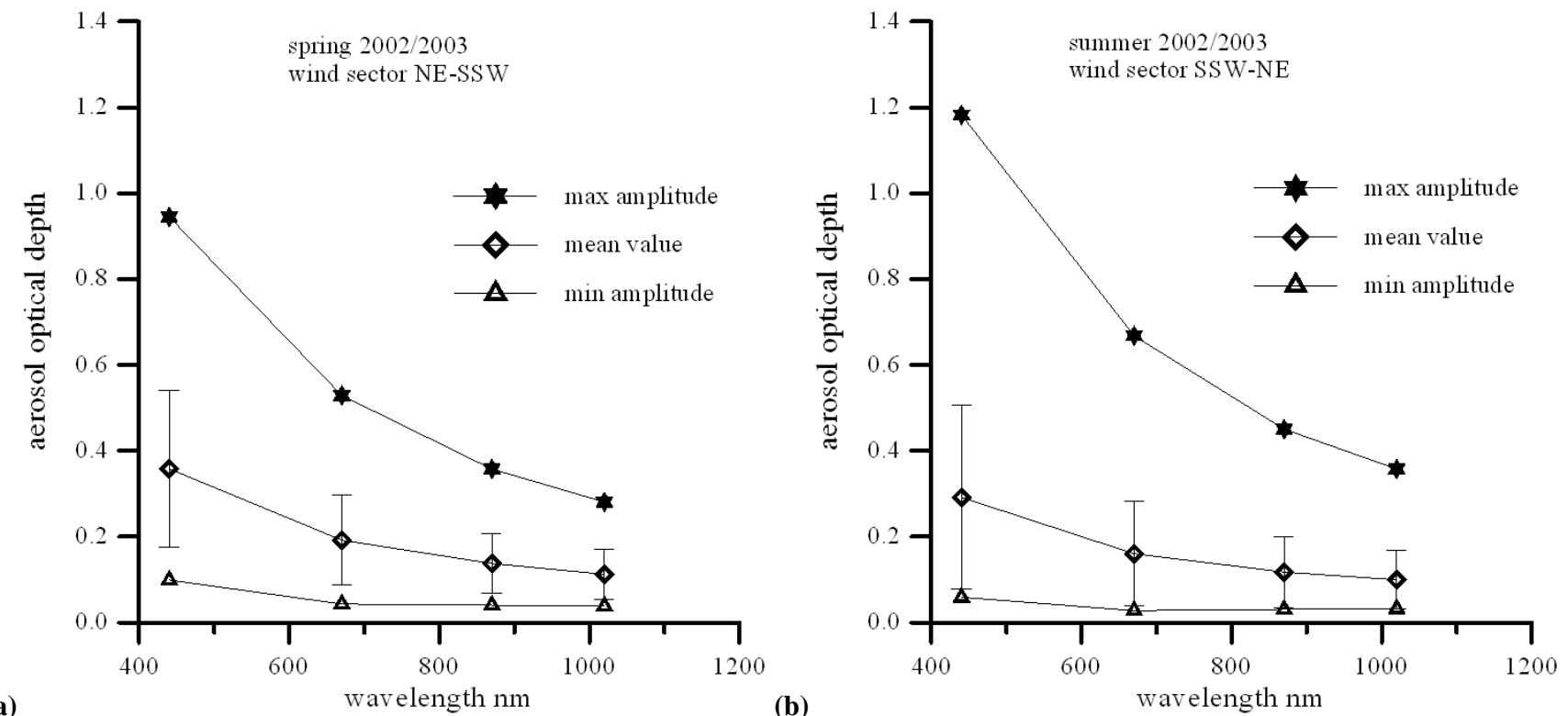

(a)

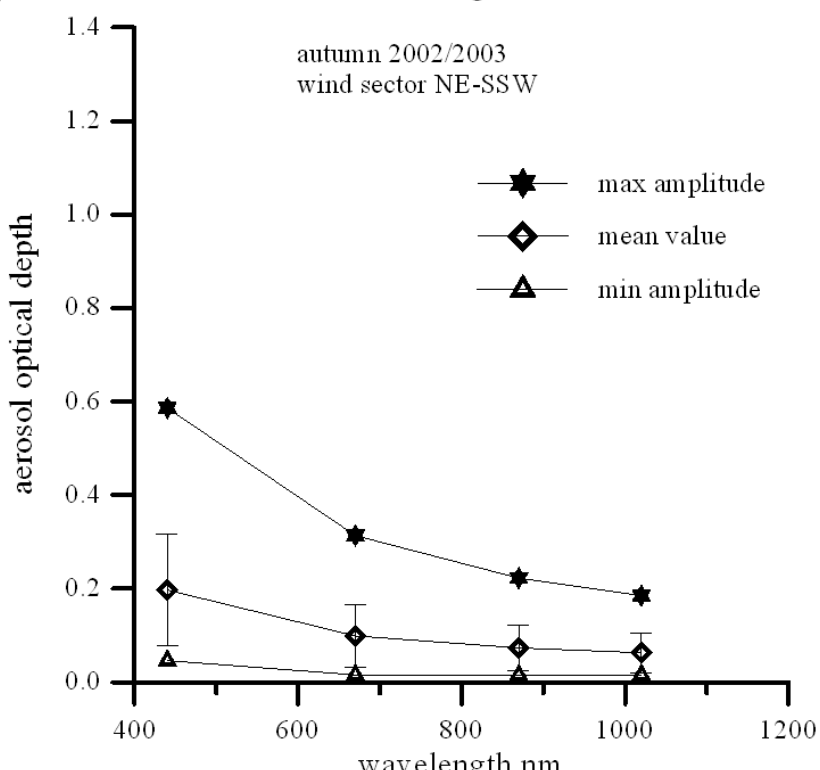

(c) (b)

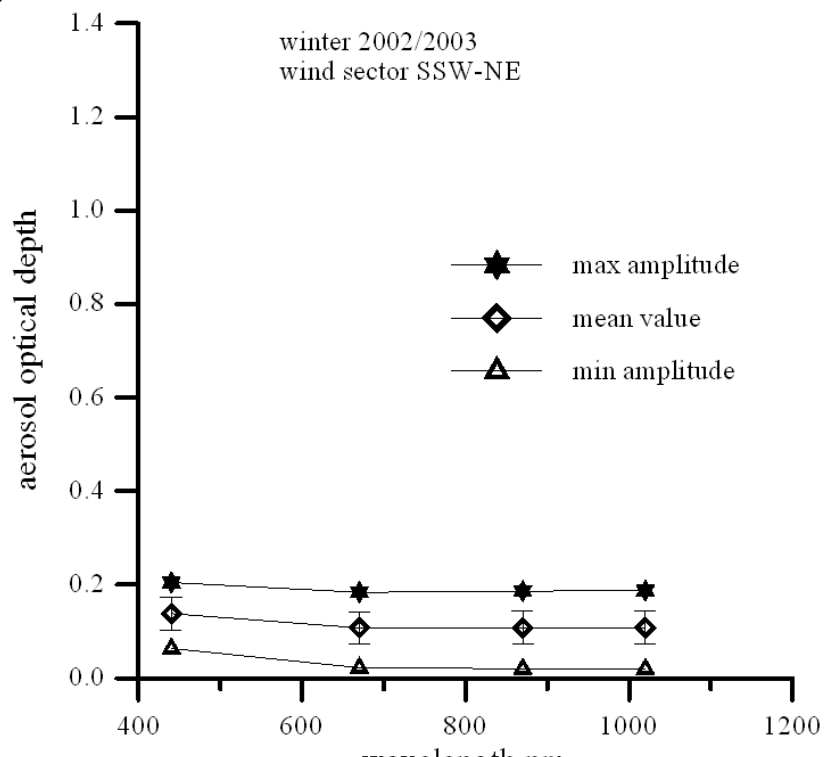

(d)

Fig. 7. The aerosol optical depth as function of wavelength for the minimum, mean and maximum values of the amplitude function, for spring (a), summer (b), autumn (c) and winter (d). The exact numbers can be calculated from Table 3 and Eq. (11). In addition the standard deviation for each mean value at a given wavelength was added.

MLH is much lower than during the spring and summer. The smallest amplitude of the diurnal variation is found for December $(110 \mathrm{~m})$ while the maximum one is observed in April (around $570 \mathrm{~m}$ ). These results corroborate our observations regarding the seasonal variations of the aerosol optical depth values.

Table 4 shows that there is no significant correlation between $\tau_{A}(555)$ and relative humidity (RH). The RH values of $83 \%$ do not explain the extremely high values of the aerosol optical depth i.e. $\tau_{A}(555)>0.6$.
To further investigate this for the Dutch North Sea coast, the data was divided into 5 subgroups, corresponding to $\tau_{A}(555)$ values ranging from 0 to 1 , with a step of 0.2 (see Table 5), for clear days $\left(\mathrm{PM}_{10}<50 \mu \mathrm{g} / \mathrm{m}^{3}\right)$ and for moderate smog $\left(50 \mu \mathrm{g} / \mathrm{m}^{3} \leq \mathrm{PM}_{10}<200 \mu \mathrm{g} / \mathrm{m}^{3}\right)$. The results show that for clean days the AOD increases linearly with $\mathrm{PM}_{10}$ for AOD up to 0.7. For higher values of $\tau_{A}(555)$ there is an opposite trend. It is noted that for these cases the number of measurements was limited and hence the statistical significance is low. For days with moderate smog a similar trend 


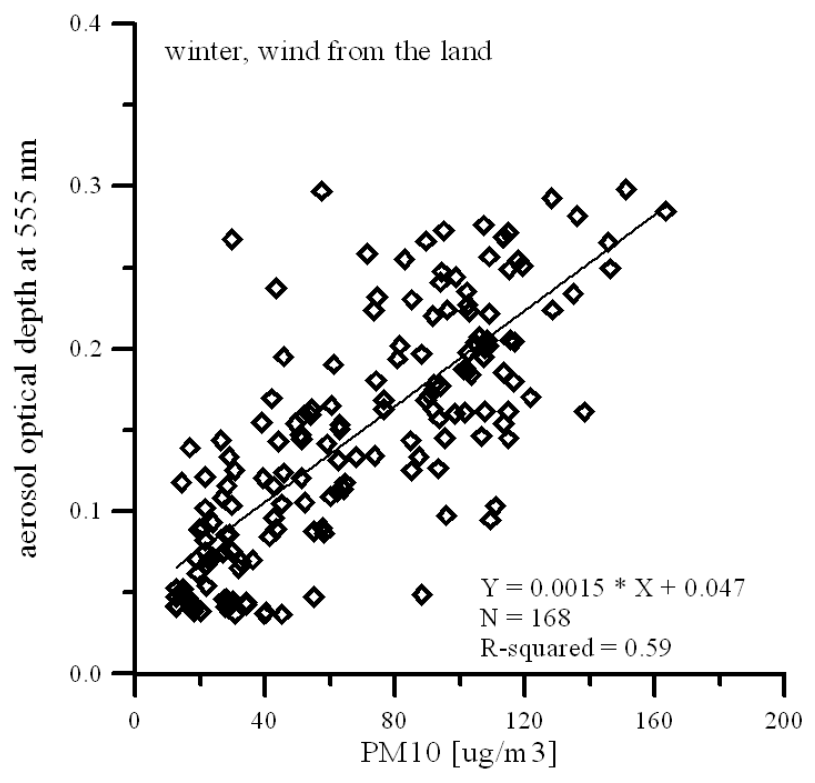

Fig. 8. Relation between the aerosol optical depth at $555 \mathrm{~nm}$ and $\mathrm{PM}_{10}$.

is observed. However, the decrease starts at lower values of $\tau_{A}(555)$, i.e. around 0.5 .

The results presented in both Tables 4 and 5 show that the values of $\tau_{A}(555)>0.6$ were registered during the days with moderate smog $\left(50 \mu \mathrm{g} / \mathrm{m}^{3} \leq \mathrm{PM}_{10}<200 \mu \mathrm{g} / \mathrm{m}^{3}\right)$ as well as during the clean days $\left(\mathrm{PM}_{10}<50 \mu \mathrm{g} / \mathrm{m}^{3}\right)$. Closer look at the data reveals that three out of 27 single measurements with $\tau_{A}(555) \geq 0.6$ (see Table 5) were registered during the spring season and the other ones during summer. The spring high values were clearly related to the high $\mathrm{PM}_{10}$ values $(72,89$ and $106 \mu \mathrm{g} / \mathrm{m}^{3}$ ). The daily mean RH values did not exceed $82 \%$ and they would not explain these high aerosol optical values.

The summer high vales of $\tau_{A}(555)>0.6$ are more difficult to interpret. They represent 6 days of measurements. Only for one day i.e. 1 of June 2003, the high values of $\tau_{A}(555)$ are clearly related to the high values of $\mathrm{PM}_{10}$ (between 56 and $89 \mu \mathrm{g} / \mathrm{m}^{3}$ ). The air mass backward trajectories indicate for the long residence time over land and the passage over large urban areas. The blue sky and relatively low values of RH (about 66\%) eliminate an argument about an influence of clouds or high humidity. Hence, the high aerosol optical depth can be explained by the high $\mathrm{PM}_{10}$ values characteristic for days with moderate smog.

The other 5 days represent more complicated situation characterized by the high daily variations of $\mathrm{PM}_{10}$ values. Because of this high variability of $\mathrm{PM}_{10}$ during a day, some measurements of the aerosol optical depth were classified as measured during "clear day" $\left(\mathrm{PM}_{10}<50 \mu \mathrm{g} / \mathrm{m}^{3}\right)$ and some as measured during "moderate smog" $\left(50 \mu \mathrm{g} / \mathrm{m}^{3} \leq \mathrm{PM}_{10}<200 \mu \mathrm{g} / \mathrm{m}^{3}\right)$. The example is
Table 4. Median values of $\tau_{A}(555), \mathrm{PM}_{10}$, wind speed $u$ and relative humidity $\mathrm{RH}$ for different ranges of amplitude function $\beta$.

\begin{tabular}{|c|c|c|c|c|c|}
\hline amplitude & $\tau_{A}(555)$ & $\mathrm{PM}_{10}\left[\frac{\mu \mathrm{g}}{\mathrm{m}^{3}}\right]$ & $u[\mathrm{~m} / \mathrm{s}]$ & $\mathrm{RH}[\%]$ & $\mathrm{N}$ \\
\hline \multicolumn{6}{|c|}{ spring, wind from the sea, SSW-NE } \\
\hline$\beta_{\max }$ & 0.554 & 95.82 & 4.6 & 82 & 8 \\
\hline$\frac{1}{2} \beta_{\max }$ & 0.367 & 69.31 & 3.2 & 81 & 32 \\
\hline$\beta \rightarrow 0$ & 0.242 & 49.70 & 3.3 & 81 & 22 \\
\hline$\frac{1}{2} \beta_{\min }$ & 0.186 & 39.41 & 3.2 & 79 & 29 \\
\hline$\beta_{\min }$ & 0.132 & 24.21 & 4.7 & 78 & 38 \\
\hline \multicolumn{6}{|c|}{ spring, wind from the land, NE-SSW } \\
\hline$\beta_{\max }$ & 0.537 & 87.69 & 4.3 & 68 & 25 \\
\hline$\frac{1}{2} \beta_{\max }$ & 0.360 & 76.50 & 4.5 & 59 & 67 \\
\hline$\beta \rightarrow 0$ & 0.255 & 83.31 & 5.0 & 55 & 41 \\
\hline$\frac{1}{2} \beta_{\min }$ & 0.192 & 63.53 & 5.2 & 60 & 75 \\
\hline$\beta_{\min }$ & 0.134 & 46.86 & 5.3 & 60 & 77 \\
\hline \multicolumn{6}{|c|}{ summer, wind from the sea, SSW-NE } \\
\hline$\beta_{\max }$ & 0.651 & 43.05 & 4.3 & 83 & 22 \\
\hline$\frac{1}{2} \beta_{\max }$ & 0.305 & 34.21 & 4.3 & 75 & 84 \\
\hline$\beta \rightarrow 0$ & 0.201 & 29.26 & 4.0 & 76 & 53 \\
\hline$\frac{1}{2} \beta_{\min }$ & 0.158 & 29.26 & 5.3 & 75 & 79 \\
\hline$\beta_{\min }$ & 0.098 & 26.84 & 6.5 & 75 & 135 \\
\hline \multicolumn{6}{|c|}{ summer, wind from the land, NE-SSW } \\
\hline$\beta_{\max }$ & 0.901 & 59.42 & 3.8 & 66 & 6 \\
\hline$\frac{1}{2} \beta_{\max }$ & 0.420 & 35.52 & 3.8 & 72 & 60 \\
\hline$\beta \rightarrow 0$ & 0.304 & 25.27 & 3.4 & 70 & 37 \\
\hline$\frac{1}{2} \beta_{\min }$ & 0.230 & 31.69 & 3.2 & 74 & 48 \\
\hline$\beta_{\min }$ & 0.129 & 30.28 & 4.3 & 71 & 48 \\
\hline \multicolumn{6}{|c|}{ autumn, wind from the sea, SSW-NE } \\
\hline$\beta_{\max }$ & 0.259 & 50.85 & 1.0 & 82 & 4 \\
\hline$\frac{1}{2} \beta_{\max }$ & 0.201 & 23.79 & 3.2 & 82 & 9 \\
\hline$\beta \rightarrow 0$ & 0.141 & 29.82 & 3.2 & 77 & 7 \\
\hline$\frac{1}{2} \beta_{\min }$ & 0.108 & 37.36 & 7.4 & 82 & 3 \\
\hline$\beta_{\min }$ & 0.079 & 23.79 & 7.4 & 76 & 13 \\
\hline \multicolumn{6}{|c|}{ autumn, wind from the land, NE-SSW } \\
\hline$\beta_{\max }$ & 0.308 & 49.26 & 2.4 & 80 & 11 \\
\hline$\frac{1}{2} \beta_{\max }$ & 0.214 & 37.88 & 7.4 & 76 & 25 \\
\hline$\beta \rightarrow 0$ & 0.124 & 15.92 & 4.3 & 77 & 17 \\
\hline$\frac{1}{2} \beta_{\min }$ & 0.100 & 21.61 & 6.4 & 76 & 21 \\
\hline$\beta_{\min }$ & 0.065 & 20.53 & 4.8 & 76 & 36 \\
\hline \multicolumn{6}{|c|}{ winter, wind from the sea, SSW-NE } \\
\hline$\beta_{\max }$ & 0.170 & 58.60 & 11.0 & 87 & 13 \\
\hline$\frac{1}{2} \beta_{\max }$ & 0.158 & 56.19 & 9.5 & 85 & 4 \\
\hline$\beta \rightarrow 0$ & 0.127 & 43.50 & 5.3 & 84 & 38 \\
\hline$\frac{1}{2} \beta_{\min }$ & 0.089 & 36.79 & 5.2 & 82 & 6 \\
\hline$\beta_{\min }$ & 0.047 & 32.67 & 5.1 & 84 & 8 \\
\hline \multicolumn{6}{|c|}{ winter, wind from the land, NE-SSW } \\
\hline$\beta_{\max }$ & 0.255 & 102.96 & 3.6 & 70 & 33 \\
\hline$\frac{1}{2} \beta_{\max }$ & 0.197 & 103.49 & 3.6 & 66 & 25 \\
\hline$\beta \rightarrow 0$ & 0.147 & 63.00 & 5.1 & 67 & 45 \\
\hline$\frac{1}{2} \beta_{\min }$ & 0.105 & 48.64 & 5.3 & 67 & 16 \\
\hline$\beta_{\min }$ & 0.052 & 26.95 & 5.3 & 73 & 49 \\
\hline
\end{tabular}

28 of August 2002 when $\mathrm{PM}_{10}$ values oscillated between 68 and $37 \mu \mathrm{g} / \mathrm{m}^{3}$. Because no other measurements (e.g. vertical structure of the boundary layer) are available this cannot be further interpreted. 

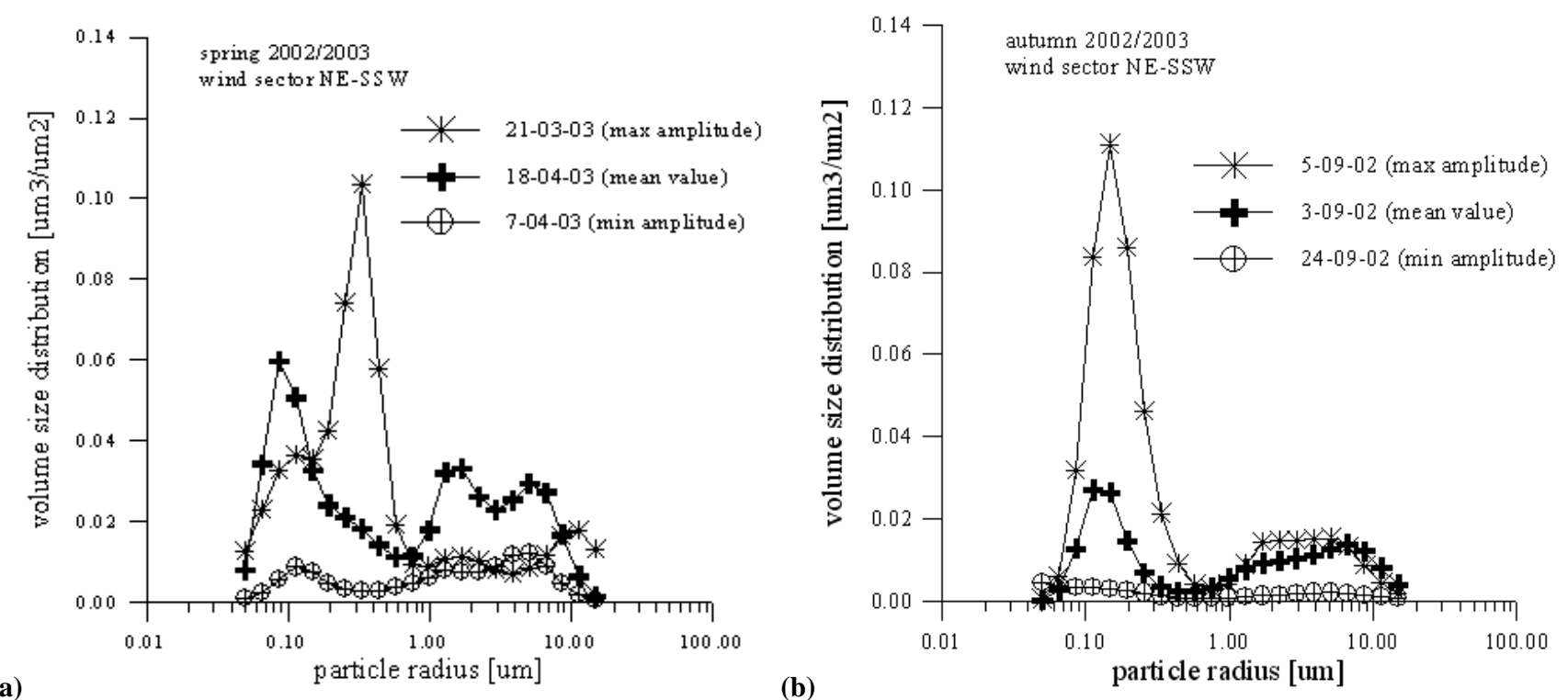

(a)

(b)
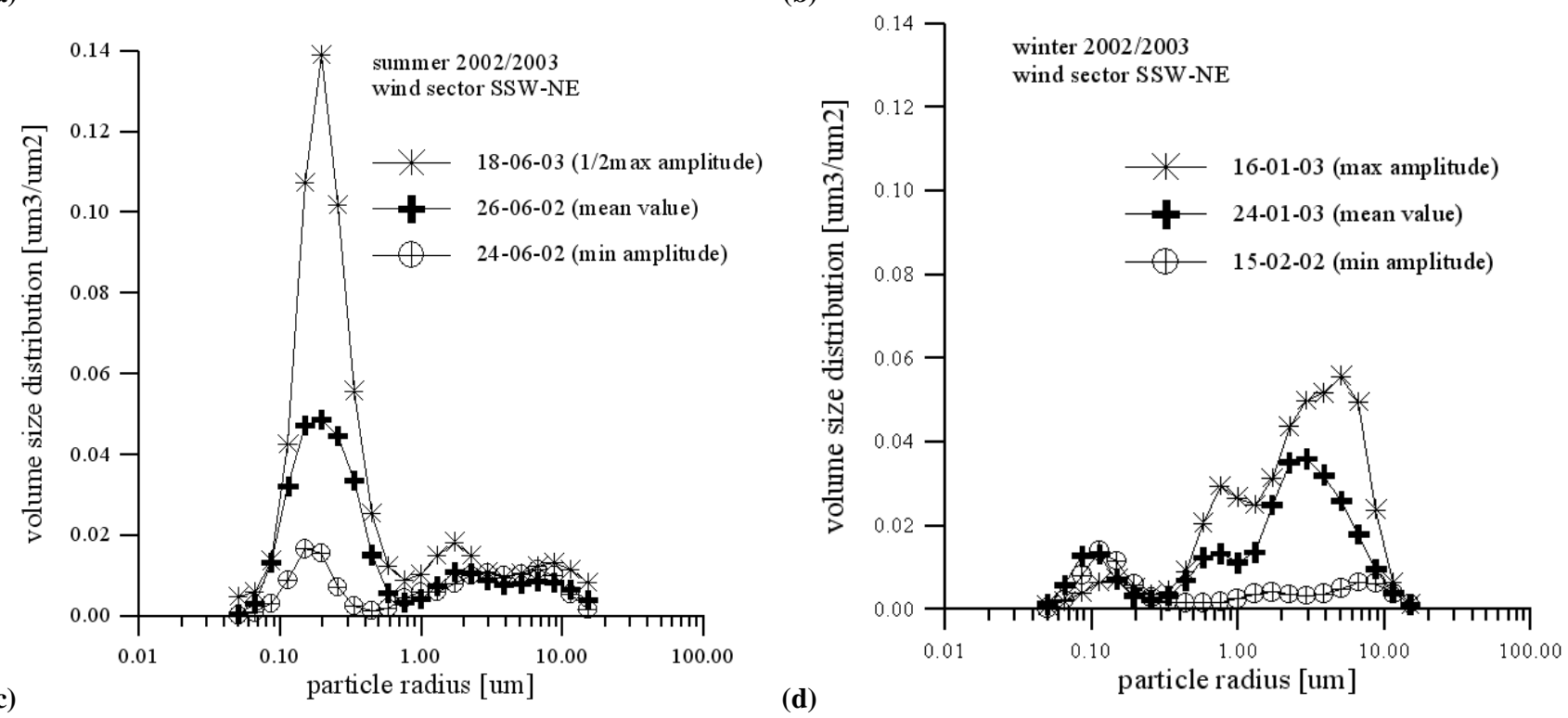

Fig. 9. Aerosol volume size distribution corresponding to the aerosol optical depth, characterized by extreme values of amplitudes for different seasons: (a) spring, (b) autumn, (c) summer (d) winter.

It is interesting to point that for the winter and autumn data there is a strong relation between the amplitude function and the wind speed $(u)$ in the wind sector SSW-NE (from sea). This relation for the autumn data is given by:

$\beta=0.2225-0.0671 \times u+0.0033 \times u^{2}$,

(Correl. Coef. $=0.63$ )

The value of the amplitude function decreases with the wind speed. Equation (12) has a very local character. However, it illustrates that there is a connection between a mathematical parameter like $\beta$ and a physical parameter like the wind speed and hence the EOF analysis results have a physical in- terpretation. The winter data in Table 4 shows a similar pattern of increasing amplitude function with the wind speed. The explanation of these differences is connected to the physical interpretation of the eigenvectors for both data sets.

\subsection{The physical interpretation of the eigenvectors}

For the interpretation of the observed optical aerosol properties the chemical composition, the volume size distribution and the air mass trajectories are used. For each mean spectrum $<\tau_{A}(\lambda)>$ and eigenvector $h_{1}(\lambda)$ the corresponding aerosol volume size distribution in the radius range 0.05 $15 \mu \mathrm{m}$ was selected from the AERONET website. Figure 9 
(a)
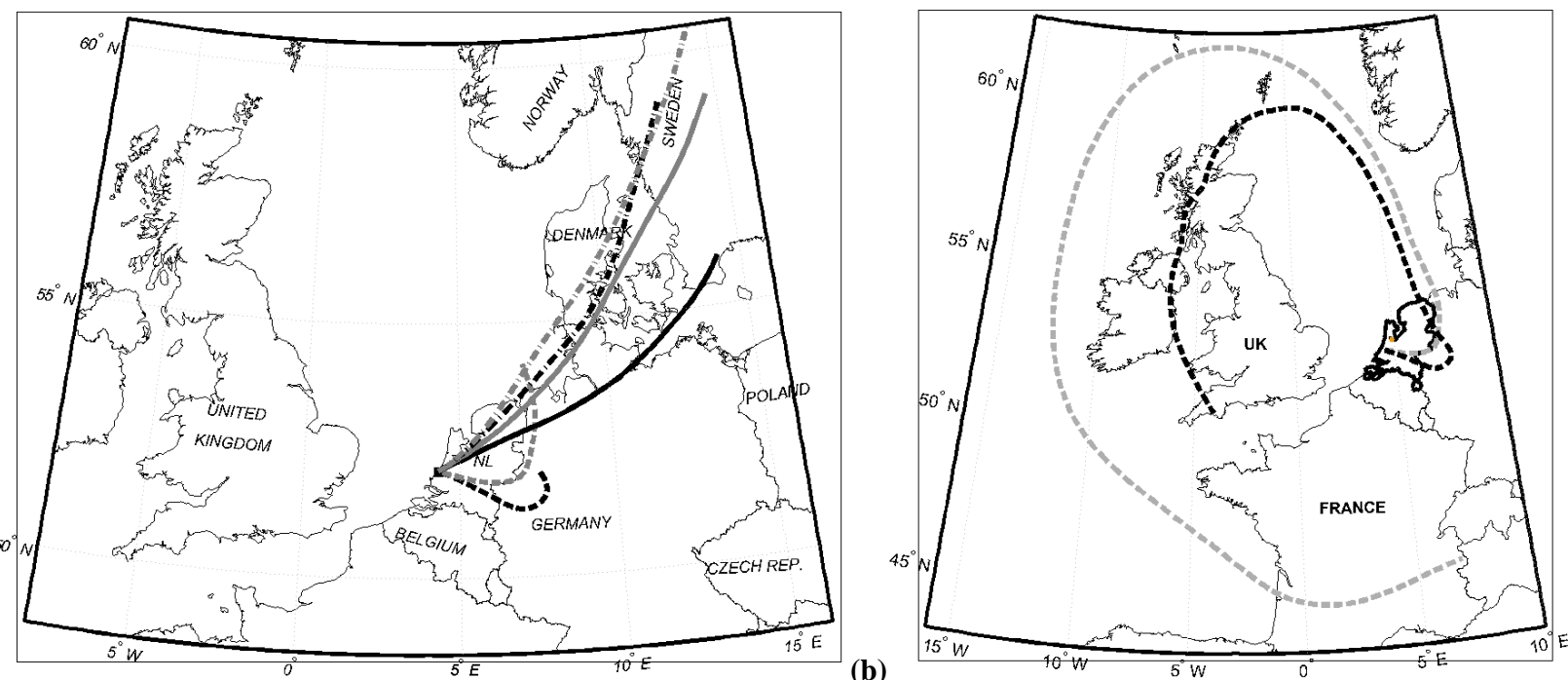

(b)

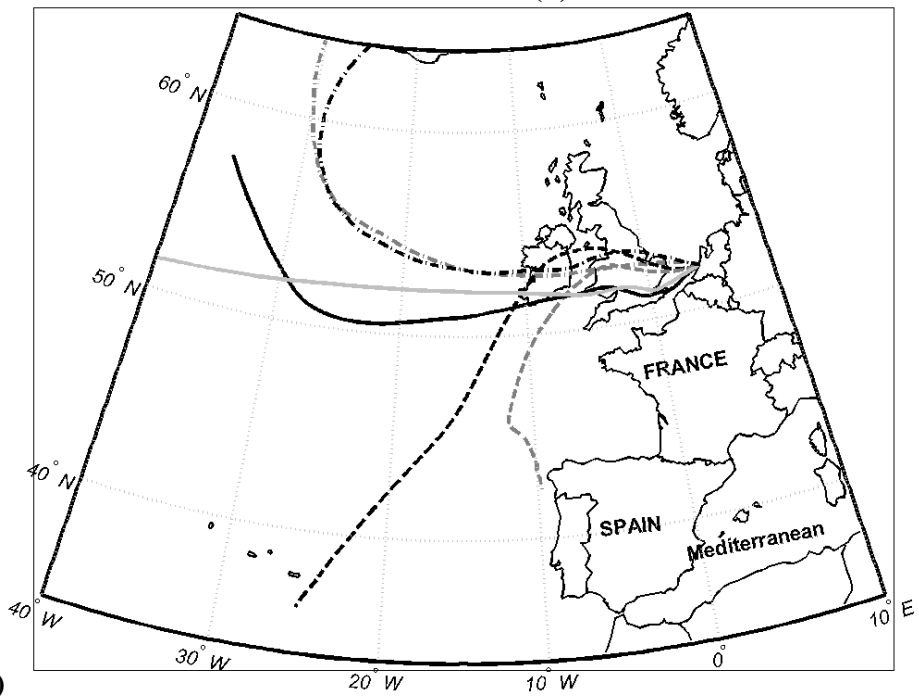

(c)

Fig. 10. Backward air mass trajectories arriving in The Hague at levels of $950 \mathrm{hPa}$ (black) and $850 \mathrm{hPa}$ (grey): (a) $24 \mathrm{~h}$ trajectories for 21 March (dashed), 18 April (solid) and 7 April (dash-dot) in 2003, (b) five days backward trajectories, for 21 March 2003 i.e. the day with the maximum amplitude $\beta_{\max }$, (c) five days trajectories for 18 June 2003 (dashed), 26 June 2002 (solid) and 24 June 2002 (dash-dot).

shows distributions corresponding to data representing the minimum, mean and maximum aerosol optical depth for different seasons and wind sectors. Examples of 1-day backward trajectories arriving in The Hague are presented in Fig. 10, for two wind sectors: NE-SSW (Fig. 10a) and SSWNE (Fig. 10c). Figure 10b shows examples of 5-day backward trajectories for the NE-SSW sector which have strong oceanic origin but due to passage over land during at least one day the maritime character has largely been lost. Below the results are discussed for different wind sectors.

\subsubsection{NE-SSW sector: off shore wind and continental air masses}

The air mass backward trajectories for the NE-SSW wind sector confirm that the air masses originate over land. The long residence time over land and in particular the passage over large urban areas cause high concentrations of fine particles and high values of the Ångström coefficients. Figures $9 \mathrm{a}-\mathrm{b}$ show the pronounced maximum in the "fine particles" range. The peak mode radius in the volume size distribution is $0.05-0.19 \mu \mathrm{m}$, except for the spring maximum volume size distribution which peaks at about $0.33 \mu \mathrm{m}$. The coarse mode has a weak minimum and coarse mode radii vary roughly between 2 and $5 \mu \mathrm{m}$. 
Table 5. Median values of $\mathrm{PM}_{10}$, aerosol optical depth $\tau_{A}(555)$, and wind speed $u$ for different ranges of $\tau_{A}(555)$.

\begin{tabular}{ccccc}
\hline range of $\tau_{A}(555)$ & $\tau_{A}(555)$ & $\mathrm{PM}_{10}\left[\mu \mathrm{g} / \mathrm{m}^{3}\right]$ & $u[\mathrm{~m} / \mathrm{s}]$ & $\mathrm{N}$ \\
\hline \multicolumn{5}{c}{$\mathrm{PM}_{10}<50$} \\
$0.0-0.2$ & 0.115 & 25.30 & 5.3 & 553 \\
$0.2-0.4$ & 0.266 & 28.21 & 3.8 & 235 \\
$0.4-0.6$ & 0.469 & 33.50 & 4.1 & 49 \\
$0.6-0.8$ & 0.640 & 36.32 & 4.2 & 12 \\
$0.8-1.0$ & 0.900 & 29.00 & 4.3 & 4 \\
$0.0-0.2$ & 0.154 & 66.91 & 5.2 & 231 \\
$0.2-0.4$ & 0.267 & 80.33 & 4.2 & 201 \\
$0.4-0.6$ & 0.486 & 82.06 & 4.3 & 70 \\
$0.6-0.8$ & 0.690 & 74.33 & 6.3 & 6 \\
$0.8-1.0$ & 0.895 & 62.78 & 3.8 & 5 \\
\hline
\end{tabular}

Figure 10a shows examples of air mass trajectories for the days corresponding to the maximum, mean and minimum aerosol optical depth on 21 March, 18 April and 7 April 2003, respectively. The maximum aerosol optical depth on 21 March is presumably due to emissions picked up over the Ruhr area in Germany. On 7 April the trajectories were more northerly and traveled over sea where the concentrations of fine particles gradually decrease due to removal processes (dry deposition) and are not replenished by local sources or by secondary production once the precursor concentrations are too low. On the other hand, coarse particles are generated at the sea surface. Due to the combined removal and production processes, the shape of the particle size distribution changes, in this case it shifted from fine to coarse particles. The wind speed that day was moderate $(5-7 \mathrm{~m} / \mathrm{s})$, and hence the coarse mode amplitude was smaller than on 18 April.

In all land (NE-SSW) cases the EOF solutions are rather uniform: the Ångström coefficients for the mean value $<\tau_{A}(\lambda)>$ and the first eigenvector $\mathrm{h}_{1}(\lambda)$ have similar values, around 1.4-1.5 (see Table 3). Such values, taking into account numbers from Table 2, indicate domination of industrial aerosol with a large contribution of sub micron particles. In winter the values of the Ångström coefficients are around 1.3 and most of the data were collected during smog events with $\mathrm{PM}_{10}$ higher than $50 \mu \mathrm{g} / \mathrm{m}^{3}$ (see Table 4). In these cases (Table 2) there is a high $\mathrm{BC}$ contribution, around $15 \%$. Hence the mean value $\left\langle\tau_{A}(\lambda)>\right.$ and the first eigenvector $h_{1}(\lambda)$ should be related to the industrial aerosol type.

An example of the relation between the amplitude function and the aerosol size distribution is given for the autumn data in Fig. 9b. The 5, 3 and 24 September 2002 represent the maximum, mean and the minimum aerosol optical depth. The aerosol size distribution corresponding to the maximum amplitude is characterized by a strong fine mode and a much weaker coarse mode. For the mean and the minimum aerosol optical depths the contribution of fine particles is less signifi-

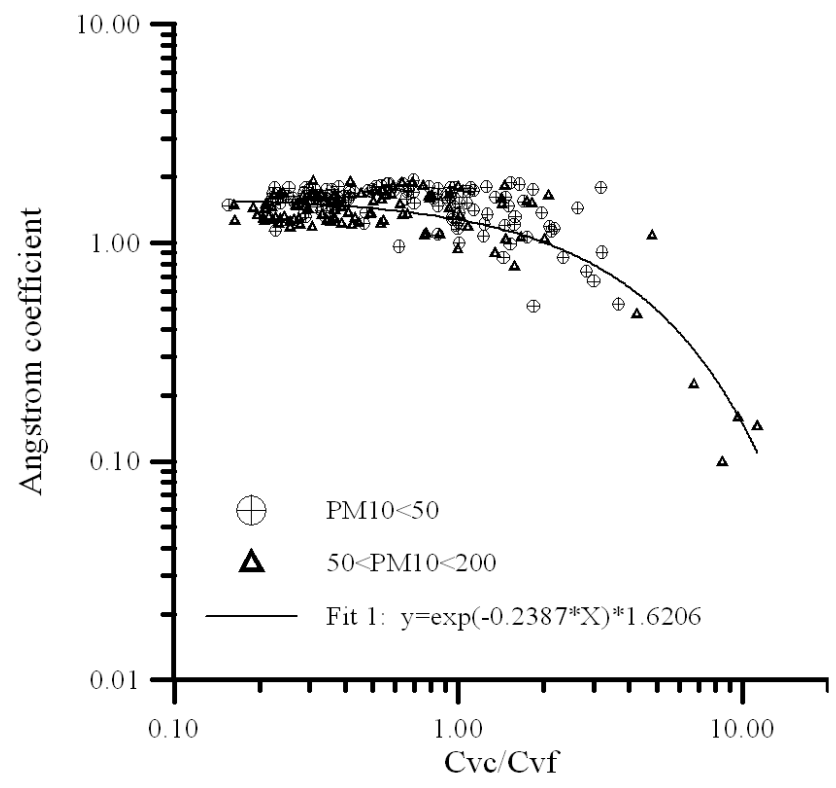

Fig. 11. Ångström coefficient versus $\mathrm{C}_{v c} / \mathrm{C}_{v f}$ for clean days $\left(\mathrm{PM}_{10}<50 \mu \mathrm{g} / \mathrm{m}^{3}\right)$ and with moderate smog $\left(50 \leq \mathrm{PM}_{10}<200 \mu \mathrm{g} / \mathrm{m}^{3}\right)$. The exponential fit is obtained for data points $(\mathrm{N}=105)$ representing days with moderate smog. The correlation coefficient is 0.798 .

cant. The Ångström coefficients are very high, i.e. larger than 1.7. The relation between fine and coarse mode $\mathrm{C}_{v f} / \mathrm{C}_{v c}$, changes from 3.25 for $\beta_{\max }$, to 1.4 for $\beta_{\min }$.

\subsubsection{SSW-NE sector: onshore wind and maritime air} masses

Figure 10c shows five days air mass back trajectories for 18 June 2003, and for 26 and 24 June 2002, i.e. the days representing the maximum, mean and the minimum aerosol optical depths for the SSW-NE wind direction sector. The 5-day backward air mass trajectories originated from the Atlantic Ocean, and were transported over Ireland, the UK and the North Sea.

Examples of the aerosol size distributions corresponding to the EOF results for the maritime (SSW-NE) wind direction sector and for two seasons (summer and winter) are presented in Figs. 9c-d. The similar aerosol size distribution, as in summer, was observed for this wind direction sector also in spring and autumn. The characteristic feature of these aerosol size distributions is that they are dominated by fine particles with the fine mode radius between 0.05 and $0.19 \mu \mathrm{m}$. The Ångström coefficients are typical for industrial aerosol. The aerosol volume size distribution for winter (Fig. 9d) is completely different because of its strong peak in the coarse mode with mode radius between 3 and $5 \mu \mathrm{m}$. For this dataset the first eigenvector $h_{1}$ represents the maritime aerosol. Table 6 summarizes the retrieved aerosol size distribution parameters for both wind direction sectors. The 
difference between parameters describing the fine mode is negligible, for the coarse mode the differences are larger.

On 18 June 2003, the high contribution of fine particles is ascribed to emissions in the major industrial area around Manchester (UK). On 26 June 2002 the source of fine particles may be major cities like London or Birmingham. On 24 June 2002 the industrial influences may come from cities such as Manchester or Belfast. In all these situations the residence time of air masses over the North Sea was too short to cause significant removal of fine particles. The wind speed was about $5 \mathrm{~m} / \mathrm{s}$, i.e. too low to cause significant white capping and thus creation of sea spray aerosol that would show up in the coarse mode.

In contrast, the winter volume size distributions were dominated by coarse particles (Fig. 9d, e.g., 16 January) and the Ångström coefficients were typical for the maritime aerosol type. The domination of the size distribution by coarse particles is anticipated to be due to elevated wind speed $(10 \mathrm{~m} / \mathrm{s})$ leading to significant production of sea spray. For other days characterized by high values of the amplitude function (see Fig. 6), i.e. a large contribution of coarse particles, the wind speed was also high. On 19 January 2002 and 3 November 2002 the wind speed was around $11 \mathrm{~m} / \mathrm{s}$, on 28 January in both 2002 and 2003 the wind speed was about $16 \mathrm{~m} / \mathrm{s}$. The total volume of coarse particles is almost 10 times higher than that of the fine mode volume $\left(\mathrm{C}_{v f /} \mathrm{C}_{v c} \approx 0.1\right)$. For the mean aerosol optical depth the contribution of the fine fraction is larger, but there still is a significant coarse fraction $\left(\mathrm{C}_{v f /} \mathrm{C}_{v c} \approx 0.24\right)$. For the minimum aerosol optical depth the fine and coarse mode contributions are similar $\left(\mathrm{C}_{v f /} \mathrm{C}_{v c} \approx 1.02\right)$. It is noted that the median sizes of both modes are in good agreement with values reported by Smirnov et al. (2003) for oceanic aerosol.

Figure 11 shows the relation between the Ångström coefficients and $\mathrm{C}_{v f /} \mathrm{C}_{v c}$ for clean days and days with moderate smog. There is not much difference between these two separate categories. For the days with moderate smog the relation between the Ångström coefficient and $\mathrm{C}_{v f /} \mathrm{C}_{v c}$ can be presented by:

$\alpha=\exp \left(-0.2387 \times C_{v c} / C_{v f}\right) \times 1.6206$,

(Corel. Coef. $=0.798)$,

The EOF solutions for the maritime wind sector (SSW-NE) show more variation than for the continental wind sector. In the summer the values of the Ångström coefficients indicate again the dominance of industrial aerosol. The contribution of BC (Table 4) is a bit lower than for the land direction, but still significant. The EOF solution representing the spring data is quite similar.

Also in the autumn the industrial aerosol type dominates. It is interesting to note that with decreasing contribution of the first eigenvector, expressed by the amplitude $\beta$, the amount of BC also decreases. The Ångström coefficient corresponding to $\beta_{\min }$ is 0.575 , indicating the presence of mar-
Table 6. Median values of the retrieved aerosol size distribution parameters.

\begin{tabular}{ccccc}
\hline & \multicolumn{2}{c}{ Fine mode } & \multicolumn{2}{c}{ Coarse mode } \\
Wind direction & $r_{v f}[\mu \mathrm{m}]$ & $\sigma_{f}$ & $r_{v c}[\mu \mathrm{m}]$ & $\sigma_{c}$ \\
\hline NE-SSW & 0.155 & 0.495 & 3.115 & 0.84 \\
SSW-NE & 0.170 & 0.460 & 2.810 & 0.82 \\
\hline
\end{tabular}

$r_{v f}, r_{v c}$ is the volume geometric mean radius for fine and coarse particles, $\sigma_{f}$ and $\sigma_{c}$ is the geometric standard deviation for fine and coarse modes.

itime aerosol. The relation between the amplitude values and the wind speed was discussed above.

In the winter the amplitude function also increases with the wind speed. The values of the Angström coefficients are 0.990 for $\beta_{\min }, 0.385$ for $\beta \rightarrow 0$, and 0.144 for $\beta_{\max }$. In this case the eigenvector can be associated with sea-salt. Table 3 shows that for the maritime wind sector in the winter $\alpha$ is negative (i.e. -0.246). This can only happen when the size distribution is governed by coarse particles, associated with the occurrence of sea spray generated over the North Sea at elevated wind speeds.

\section{Conclusions}

Aerosol physical and optical properties derived from sun photometer measurements at a coastal site near The Hague are interpreted in terms of meteorological conditions and air mass trajectories, as well as data on $\mathrm{PM}_{10}$ and $\mathrm{BC}$ available from the network at nearby site. The principal conclusions are:

1. The EOF method applied to the aerosol optical depth data allowed for the analysis of all data using the mean spectrum, the first eigenvector and the amplitude function. The mean spectrum and the first eigenvector include spectral information that can be related to the chemical measurements and the aerosol size distribution. The amplitude function can be interpreted as the contribution of the first eigenvector to the total aerosol optical depth.

2. The EOF results show that the industrial aerosol type, characterized by high Ångström coefficients (larger than 1.4-1.5), dominates when the wind direction is from land (NE-SSW) due to the vicinity of large cities and industrial areas. Industrial aerosols may be also observed when the wind direction is from the North Sea but the air mass has been influenced by transport over polluted areas, such as industrial and urban areas in the United Kingdom.

3. The average bimodal volume size distribution is characterized by a fine mode with a radius $\mathrm{r}_{v f}$ of $0.16 \mu \mathrm{m}$ and 
a coarse mode with $r_{v c}$ of $3.12 \mu \mathrm{m}$. The size distribution for the maritime aerosol type has a fine mode with $r_{v f}=0.17 \mu \mathrm{m}$, and a coarse mode with $r_{v c}=2.81 \mu \mathrm{m}$, in good agreement with other observations (Smirnov et al., 2003).

4. The maritime aerosol type observed in The Hague is an example of a mixture of maritime and "polluted" aerosols in a ratio that varies with the distance and the source. Sea spray aerosol is generated over the North Sea at moderate and high wind speeds and it affects the optical properties that are observed at the site in The Hague (ca. $2.5 \mathrm{~km}$ from the sea) in westerly winds. A correlation between the coarse particle mode and wind speed, ascribed to the generation of sea spray aerosol, has been identified. The fine particle mode is due to pollutants generated locally and in the areas upwind from the site.

Acknowledgements. The authors thank T. L. Kucsera and A. M. Thompson at NASA/Goddard for back-trajectories available at the aeronet.gsfc.nasa.gov website. The Royal Netherlands Meteorological Institute KNMI is kindly acknowledged for archive meteorological data (wind speed, wind direction and relative humidity). The National Institute for Public Health and the Environment (RIVM) is acknowledged the chemical measurements available at the http://www.rivm.nl website. The work was supported by the EU FP5 DAEDALUS project (EESD-ENV-2002GMES, 33197).

Edited by: J. Curtius

\section{References}

Ångström, A.: On the atmospheric transmission of sun radiation and on dust in the air, Geogr. Ann., 11, 156-166, 1929.

Buringh, E. and Opperhuizen, A. (Eds.): On health risks of ambient PM in the Netherlands, RIVM report 650010032, pp. 380 (http: //www.mnp.nl/bibliotheek/rapporten/650010032.pdf), 2002.

Chu, D. A., Kaufman, Y. J., Zibordi, G., Chern, J. D., Mao, J., Li, C., and Holben, B. N.: Global monitoring of air pollution over land from the Earth Observing System-Terra Moderate Resolution Imaging Spectroradiometer (MODIS), J. Geophys. Res., 108, 4661, doi:10.1029/2002JD003179, 2003.

De Haij, M., Wauben, W., and Klein Baltink, H.: Determination of mixing layer height from ceilometer backscatter profiles, Proc. SPIE, vol. 6362, 63620R, doi:10.1117/12691050, 2006.

De Leeuw, G., Neele, F. P., Hill, M., Smith, M. H., and Vignati, E.: Sea spray aerosol production by waves breaking in the surf zone, J. Geophys. Res., 105(D2), 29 397-29409, 2000.

Dubovik, O. and King, M. D.: A flexible inversion algorithm for retrieval of aerosol optical properties from Sun and sky radiance measurements, J. Geophys. Res., 105, 20 673-20 696, 2000.

Dubovik, O., Smirnov, A., Holben, B. N., King, M. D., Kaufman, Y. J., Eck, T. F., and Slutsker, I.: Accuracy assessments of aerosol optical properties retrieved from AERONET sun and sky-radiance measurements, J. Geophys. Res., 105, 9791-9806, 2000 .
Dubovik, O., Holben, B. N., Lapyonok, T., Sinyuk, A., Mishchenko, M. I., Yang, P., and Slutsker, I.: Non-spherical aerosol retrieval method employing light scattering by spheriods, Geophys. Res. Lett., 29, 541-544, 2002.

Eck, T. F., Holben, B. N., Reid, J. S., Dubovik, O., Smirnov, A., O'Neill, N. T., Slutsker, I., and Kinne, S.: Wavelength dependence of the optical depth of biomass burning, urban, and desert dust aerosol, J. Geophys. Res., 104, 31 333-31 350, 1999.

Engel-Cox, J. A., Holloman, C. H., Coutant, B. W., and Hoff, R. M.: Qualitative and quantitative evaluation of MODIS satellite sensor data for regional and urban scale air quality, Atmos. Environ., 38, 2495-2509, 2004.

Hammingh, P. (Ed.): Air Quality. Annual Survey 1998 and 1999 (in Dutch), National Institute of Public Health and the Environment, report 725301006, Bilthoven, the Netherlands, 2001.

Hess, M., Koepke, P., and Schult, I.: Optical properties of aerosols and clouds: The software package OPAC, B. Am. Meteor. Soc., 79, 831-844, 1998.

Holben, B. N., Eck, T. F., Slutsker, I., Tanre, D., Buis, J. P., Setzer, A., Vermote, E., Reagan, J. A., Kaufman, Y., Nakajima, T., Lavenu, F., Jankowiak, I., and Smirnov, A.: AERONET- A federated instrument network and data archive for aerosol characterisation, Rem. Sens. Environ., 66(1), 1-16, 1998.

Holben, B. N., Tanre, D., Smirnov, A., et al.: An emerging ground-based aerosol climatology: Aerosol optical depth from AERONET, J. Geophys. Res., 106, 12 067-12 097, 2001.

Hutchison, K. D.: Applications of MODIS satellite data and products for monitoring air quality in the state of Texas, Atmos. Environ., 37, 2403-2412, 2003.

Jankowski, A.: The application of EOF in the analysis of the variability of water temperature, salinity and density in selected regions of the Norwegian Sea, Oceanologia, 35, 27-60, 1994.

Kusmierczyk-Michulec, J. and Darecki, M.: The aerosol optical thickness over the Baltic Sea, Oceanologia, 38(4), 423-435, 1996.

Kusmierczyk-Michulec, J. and Marks, R.: The influence of sea-salt aerosols on the atmospheric extinction over the Baltic and the North Seas, J. Aerosol Sci., 31(11), 1299-1316, 2000.

Kusmierczyk-Michulec, J., Krueger, O., and Marks, R.: Aerosol influence on the sea-viewing wide-field-of-view sensor bands: Extinction measurements in a marine summer atmosphere over the Baltic Sea, J. Geophys. Res, 104(D12), 14 293-14 307, 1999.

Kusmierczyk-Michulec, J., de Leeuw, G., and Robles Gonzalez, C.: Empirical relationships between aerosol mass concentrations and the Ångstrom parameter, Geophys. Res. Let., 29(7), 491-494, doi:10.1029/2001GL014128, 2002.

Lamberts, C. W. and de Leeuw, G.: Aerosol-induced visibility reduction in The Netherlands, in: Aerosols, edited by: Lee, S. D., Schneider, T., Grant, L. D., and Verkerk, P. J., Lewis Publishers, Chelsea, Michigan, pp.1221, 1986.

Lorenz, E. N.: Empirical orthogonal functions and statistical weather, Statistical forecasting project, Sci. Rep. No.1, Mass. Inst. Tech., Dept. Meteor., Cambridge, 49 pp., 1956.

Nielsen, P. B.: On empirical orthogonal functions (EOF) and their use for analysis of the Baltic Sea level, Rep. 40, Inst. Fys. Oceanogr., Københavns Univ., Copenhagen, pp.37, 1979.

Pickering, K. E., Thompson, A. M., Kim, H., DeCaria, A. J., Pfister, L., Kucsera, T. L., Witte, J. C., Avery, M. A., Blake, D. R., Crawford, J. H., Heikes, B. G., Sachse, G. W., Sandholm, S. T., 
and Talbot, R. W.: Trace gas transport and scavenging in PEMTropics B South Pacific Covergence Zone convection, J. Geophys. Res., 106, 32 591-32 602, 2001.

Preisendorfer, R. W.: Principal component analysis in meteorology and oceanography, Elsevier, Amsterdam- Oxford-New YorkTokyo, pp.425, 1988.

Ralston, A.: Introduction to numerical analysis, Pol. Wydaw. Nauk., Warszawa, pp.589, 1975.

Remer, L. A. and Kaufman, Y. J.: Dynamic aerosol model: Urban/industrial aerosol, J. Geophys. Res., 103, 13859-13871, 1998.

Shettle, E. P. and Fenn, R. W.: Models of aerosols of lower troposphere and the effect of humidity variations on their optical properties, AFCRL Tech. Rep. 79 0214, Air Force Cambridge Research Laboratory, Hanscom Air Force Base, MA, 10 pp, 1979.

Schoeberl, M. R. and Newman, P. A.: A multiple-level trajectory analysis of vortex filaments, J. Geophys. Res., 100, 25 801$25816,1995$.
Smirnov, A., Holben, B. N., Eck, T. F., Dubovik, O., and Slutsker, I.: Cloud screening and quality control algorithms for the AERONET data base, Rem. Sens. Environ., 73(3), 337-349, 2000.

Smirnov, A., Holben, B. N., Eck, T. F., Dubovik, O., and Slutsker, I.: Effect of wind speed on columnar aerosol optical properties at Midway Island, J. Geophys. Res., 108(D24), 4802, doi:10.1029/2003JD003879, 2003.

Van Elzakker, B. G.: Monitoring activities in the Dutch National Air Quality Monitoring Network in 2000, report 723101055, Rijksinstituut voor volksgezondheid en Milieu (RIVM), Bilthoven, The Netherlands, 2000.

Wang, J. and Christopher, S. A.: Intercomparison between satellitederived aerosol optical thickness and $\mathrm{PM}_{2.5}$ mass: implications for air quality studies, Geophys. Res. Lett., 30(21), 2095, doi:10.1029/2003GL018174, 2003. 